\title{
North Carolina Library Association Executive Board Meeting Minutes
}

\author{
January 22, 2010
}

\begin{abstract}
Attending
Sherwin Rice (President), Tammy Baggett (Director), Phillip Barton (Past President), Evelyn Blount (REMCO), Mary Boone (State Library), Wanda Brown (Vice-President), Robert Burgin (Website), Phillip Cherry (REMCO), Carol Cramer (Finance), Steven Cramer (BLINC), Mimi Curlee (GRS), Laura Davidson (Secretary), Cynthia Dye (YSS), Kem Ellis (LAMS), Jacqueline Frye (NCLPA), Mary Goodrum (PLS), Jennifer Hanft (Membership), John Harer (IF), Jennie Hunt (WILR), Rebecca Kemp (RTSS), Emily King (NMRT), Priscilla Lewis (Operations), Rodney Lippard (ALA Councilor), Elizabeth Meehan-Black (SELA Representative), Jennifer Noga (CJCS), Todd Nuckolls (Archives), Timothy Owens (Constitution), Kim Parrott (Admin Asst), Donna Phillips (LIT), Mark Sanders (RASS), Dale Sauter (RTSC), Mary Sizemore (Treasurer elect), Elizabeth Skinner (Director), Andrea Tullos (Treasurer), Carol Walters (Public Policy), Carolyn Willis (CUS), John Via (TNT).
\end{abstract}

\section{Call to Order}

The meeting was called to order by Sherwin Rice at 10:12am. Dale Cousins welcomed everyone to the Cameron Village Branch.

The agenda was approved. The minutes of the July 23, 2009 meeting were approved with only one correction to a name.

The dates and locations of the meetings for this year were announced. They are:

- April 23, Hemphill Public Library, Greensboro

- July 23, Barton College, Wilson

- October 22, South Regional Public Library, Durham

\section{Parliamentary Procedure Review} Phil Barton (Handout)

A review of executive board policies and procedures was conducted. Policies are available in the NCLA Handbook, Appendix $\mathrm{H}$, (http://www.nclaonline.org/handbook/ NCLAhandbook2009-Final.htm).

Note that motions should be emailed to the entire executive board in advance of the board meeting via Kim whenever possible.

\section{Treasurer's Report}

Copies of the 2009 budget and the December 31 financial report and fund balances were distributed by Andrea Tullos. Andrea reported that sections and roundtables have been given quarterly reports for last year and that 2009 operational budgets have already been posted. She reminded everyone that the NCLA budget operates on a calendar year, not a fiscal year. Andrea thanked sections and roundtables for using their balances during the conference. She noted that the scholarships distributed in 3rd quarter and interest earned in the last quarter were not reflected on the report. The 2009 conference has a positive balance.
NCLA did not meet goals set for revenue for 2009. Primarily, this was because of lower dues revenue. The revenue shortfall was covered by 2007 conference profits.

\section{Budget}

Carol Cramer distributed copies of the proposed 2010 budget. Carol reviewed projected income and expenses. Revenue from the 2005 conference has been spent as well as some of the remaining 2007 conference income. The finance committee assumed that dues and royalty income will continue to be low in 2010. The committee recommended deleting the executive board meeting budget, covering only ALA registration for the ALA Councilor, and decreasing the budgets for legislative day, NC Libraries, and Tarbeel Libraries. Even with these changes, a $\$ 17,000$ gap remains between projected revenue and organization expenses.

A motion to accept a budget with a $\$ 17,044.41$ deficit was made by the finance committee. Discussion followed on recommended cuts and ways to close the gap.

Phillip Barton made a motion to amend the budget proposal by accepting the budget but making up the deficit plus cost of legislative day $(\$ 6,500)$ by, first, drawing all funds from Trustees $(\$ 4,660)$ and School Libraries $(\$ 2,787)$ and, second, by taking half the 2009 conference profits $(\$ 5,500)$ and, finally, by taking the remaining shortfall from section and roundtable budgets. Robert Burgin seconded. Discussion followed. The amendment was withdrawn.

Rodney Lippard made a motion to amend the budget proposal as prepared, including $\$ 5,000$ for legislative day. The resulting deficit will be made up with $34 \%$ of fund balance from each section and roundtable. Robert Burgin seconded.
Discussion followed with particular emphasis on expanding NCLA membership. All sections and roundtables should appoint a representative to the membership committee by the next meeting of the executive board. The amendment passed unanimously.

The finances committee's proposed budget as amended also passed unanimously.

\section{State Library Update}

Mary Boone shared budget challenges and initiatives at the State Library. Of note, the State Library has already experienced a $5 \%$ budget sweep this year. Budget requests for next year are anticipating either a $3 \%, 5 \%$ or $7 \%$ reduction. The library is partnering with Web Junction which has received an IMLS grant for expanding job search training for public librarians.

The Gates Foundation is funding a consultant to help with the library's Federal stimulus grant application to help public libraries provide employment support in counties with high unemployment. An LSTA grant in partnership with ECU and UNC-CH will digitize historical North Carolina publications. LSTA grant proposals are due by February 18. North Carolina is one of only 11 states giving more than $50 \%$ of its LSTA funds to libraries. The next phase of NC-ECHO will involve partnering with UNC-CH to digitize interesting cultural information held by institutions around the state (starting with yearbooks).

In the discussion that followed, Boone noted that the State Library has not had to return Federal funds yet, but that will probably happen over the next few years as the state fails to meet our "maintenance of effort." Phillip Cherry noted the importance of the census project this spring. Rodney Lippard discussed the ALA Snapshot project. 


\section{Guidelines for Sections and Roundtables}

Timothy Owen reviewed the policies and processes associated with the operations of NCLA sections and roundtables.

\section{Section/Round Table Reports}

Business Librarianship Section

Steve Cramer reported on the success of the BLINC sessions at the 2009 Conference, the plans for quarterly workshops, the beginning of the askBLINC reference email reference service, and the status of the Business Research Support Initiative.

College and University Section

Carolyn Willis reported a number of workshops planned for the coming year by CUS, including a mini-conference on instruction cosponsored by the CJCS. CUS has also approved the formation of a distance education interest group.

Community and Junior

College Libraries Section

Jennifer Noga reported on officer elections and 2009 conference sessions. Officers continue to develop plans for the coming year.

Government Resources Section

Mimi Curlee reported on programming plans for the section and brought several motions from the section to the Executive Board.

Motion: The NCLA Board reevaluate reimbursing travel expenses/honorariums for speakers and members and post the report online. The issue reappears and needs clear understanding. Discussion followed. Rodney Lippard proposed a substitute motion to refer the original motion to the Constitution, Codes, and Handbook Committee. Phillip Barton seconded the motion. The substitute motion was approved.

Motion: The NCLA Board investigated providing web conferencing for Executive Board meetings and for sections and roundtables to use in order to cut down on exclusion of members who can't travel. Discussion followed. Rodney Lippard proposed an amendment: The Operations Committee will look into this and have a report by the July meeting. Dale Sauter seconded. The amendment was approved and the amended motion was approved.

Motion: The Biennial Conference Committee created a Section Guide and Checklist to better explain what the sections are responsible for and applicable deadlines. This motion was withdrawn and offered to the conference committee as a suggestion.
Motion: The NCLA Executive Board decided if the objective of its Conference is to educate as many as possible or to increase attendance. If it is to educate, film more sessions and make them available on the website. After discussion, the motion was withdrawn.

\section{Library Administration and Management Section \\ Kem Ellis - No report}

Literacy Roundtable

Donna Phillips (for Pauletta Bracy) reported on program planning for the upcoming biennium.

\section{New Members Round Table}

Emily King reported on the continuing success of the networking events.

NC Library Paraprofessional Association Jackie Frye reported that NCLPA is planning quarterly workshops and encouraging libraries to invite neighbors for training.

\section{Public Library Section}

MJ Goodrum - No report, however NCPLDA has asked if NCLA would be willing to assume responsibility for collecting and paying ProQuest for Ancestry.com. The association has been advised that it cannot handle the Ancestry.com contract with its current non-profit type. It is pursuing filing for the appropriate non-profit status. NCPLDA will continue to coordinate collection of funds to pay EBSCO and is asking NCLA to serve as a pass-through only. The contract cost is about $\$ 90,000$ and payment for the year is due in February.

Phillip Barton made a motion to work with NCPLDA to handle the funds for paying for Ancestry.com this year and will make that payment for them when we have the funds from Robert Busko (NCPLDA treasurer). The motion was seconded. The motion was approved. ProQuest will invoice NCLA.

Reference and Adult Services Section

Mark Saunders - While the next section meeting occurs after the Board meeting, plans for the coming year include revamping the section web presence and organizing a workshop.

Round Table for Ethnic Minority Concerns Evelyn Blount - When a member of the REMCo Executive Board resigned recently, the members of the Board noticed that our current bylaws only address the replacement of the Chair and Chair-Elect in the interval between biennial elections. Motion: The REMCo Executive Board recommends the following changes to Article VIII, no. 6 of the
REMCo bylaws:

Old Bylaw

In the event of absence, death, disability or resignation of the Chairperson and the Chair-Elect during the interval between the biennial meetings, the Executive Committee shall fill such vacancies by the appointment of members to those offices. Such appointments shall remain in force until the next regular meeting of the Round Table.

New Bylaw

In the event of absence, death, disability or resignation of any officer during the interval between the biennial meetings, the REMCo Executive Board shall fill such a vacancy or vacancies by the appointment of a member of the Round Table to fill the unexpired term(s). Such an appointment or appointments shall remain in force until the next biennial election. The motion was approved.

Resources and Technical Services Section Rebecca Kemp reported that the section is beginning to plan for a fall workshop. They are concerned about possible conflicts with other section workshops. Robert Burgin reminded everyone to use the website calendar or send scheduled events to Kim Parrot.

Special Collections Round Table Dale Sauter - A change in round table leadership was required after the election period. Suzanne Wise resigned as Director, replaced by Ted Waller. Jason Tomberlin is continuing as Vice-Chair for this biennium. The round table is hoping to plan an offconference year event for this year.

Technology and Trends Round Table John Via for Ed Hirst - Officers were not elected for the round table at the annual meeting.

Women's Issues in Libraries Round Table Jennie Hunt - No report

Youth Services Section

Cynthia Dye - The 2009 conference sessions were well attended. The section is planning its biennial fall retreat because of executive board funding decisions those plans may change.

\section{Committee Reports}

\section{Archives}

Todd Nuckolls - No report. Todd has just accepted this role for the Association.

\section{Conference 2011}

Wanda Brown - No report. Wanda asked for volunteers to work with conference planning.

Constitution, Codes and Handbook

Timothy Owens expressed his thanks to 
the prior committee for their revision of handbook and website. The committee is working on a process for making changes. He reminded everyone to take a look at the handbook and bylaws for NCLA and for their specific sections. Questions about the constitution, codes or handbook should be directed to the NCLA President who will work with the committee to answer them.

Finance

Carol Cramer

The 2010 budget has been approved. Revised section budgets will be posted as soon as possible. There will be no project grants this year.

\section{Endowment - VACANT}

Phillip Barton: There is no report and no committee. He is chairing the endowment committee. Biennium projects include developing better member communication; clarifying the endowment purpose; considering adding funds held in trust in the operating budget to the endowment (e.g. scholarship funds). The previous endowment draw down was reinvested in the endowment.

\section{Intellectual Freedom}

John Harer

The committee has two new members. It is assisting with the Wayne County community read program.

\section{Leadership Institute - VACANT}

There is no committee yet, just the institute co-facilitators, Mark Livingstone and Kem
Ellis. However, the Executive Board needs to decide institute charges right away.

Phillip Barton made a motion that we agree to charge a fee of $\$ 1000$ per participant for the Leadership Institute this year. Motion was seconded by Kem Ellis.

The budget for institute is $\$ 60,000$. There is a fund balance of almost $\$ 15,000$, and endowment income of about $\$ 2,000$. We expect 45 participants and 8 mentors at the institute this year.

The motion was approved.

Membership

Jennifer Hanft - The membership committee has been active. They have attended library school orientations for recruiting student members. They did outreach to Wake County Public Libraries at their staff development day. They are happy to sponsor membership table at any section/round table workshop or conference.

\section{Nominating}

Phil Barton - No report

\section{Operations}

Priscilla Lewis/Kim Parrott (Handout) - Kim reviewed key Association operations policies with the Board. Remember to get a receipt for every purchase on behalf of the Association and send to Kim.
Public Policy

Carol Walters emphasized the importance of being good advocates for libraries. Instead of a library legislative day, a rally is scheduled for the last day of the American Library Association's annual conference. NCLA will be sponsoring a bus to bring people to the rally. Participants will be encouraged to visit legislators after the rally.

\section{Scholarships}

Lisa Williams - No report

\section{Website Redesign Committee}

Robert Burgin - There is no committee. The new website is Drupal based. A training session for section, round table and committee web administrators is scheduled for Feb. 12. Website issues are now the responsibility of the NCLA Website Committee.

\section{Other Reports}

\section{ALA Council}

Rodney Lippard gave highlights from his report (available online) including the ALA Snapshot Project, the Merritt Fund for displaced library employees, and his visits to library school classes.

\section{SELA Representative}

Betty Meehan-Black announced the next Southeastern Library Association Conference in Little Rock from September 26-28, 2010 in conjunction with the Arkansas Library Association. Proposal forms are available on the SELA website. She also talked about the SELA mentoring program.

\section{Looking for help with collection development?}

If you want to expand your library's collection of novels set in North Carolina, you should visit the Read North Carolina Novels blog hosted by the North Carolina Collection at the University of North Carolina at Chapel Hill (http://www.lib.unc.edu/blogs/ncnovels/).

If your interest in North Caroliniana is more general, both the North Carolina Collection at East Carolina University and the North Carolina Collection at UNC-Chapel Hill regularly post lists of new additions to their collections.

The addresses for those sites are:

http://www.ecu.edu/cs-lib/ncc/profs.cfm

http://www.lib.unc.edu/blogs/ncm/index.php/whats-new-in-the-north-carolina-collection/ 